\title{
Development of Enterprises in the Spatial Structure of Industry (Based on Research of the Industrial Geography Commission of the Polish Geographical Society)
}

\begin{abstract}
The processes of socio-economic development take place at the different-scale spatial systems within the geographical space (from the local through the national to the global level). The geographical space covers a diverse natural space, various potential of the socio-economic and cultural space, as well as active and passive relations that occur between their elements. One of the important parts of the socio-economic space is the spatial structure of industry whose fundamental element is an industrial enterprise.

The theme of this discussion is the issue of the behaviour of an industrial enterprise in the spatial structure of industry in the light of Polish research in the field of industrial geography. Specific attention will be paid to the development and functions of industrial enterprise in the spatial structure of industry.
\end{abstract}

Key words: development; enterprise; industry; spatial structure

\section{INTRODUCTION}

Increasing socio-economic development requires more in-depth analysis of changes taking place in the geographical space, including those in the spatial structure of industry. The studies should be used for assessing these processes and developing the rational concept of their reconstruction in relation to the rules of economic and social efficiency.

In recent years, the field of geographical sciences has shown less interest in the issues of industrial geography, including the development of industrial enterprises. This is largely due to the difficulty in accessing source materials, which results from the expansion of secrets of technological processes, production potentials and market linkages, especially in private industrial enterprises and in companies taken over by multinational corporations. In addition, in Polish national conditions a wrong idea was adopted that along with finishing the phase of industrial development and entering the post-industrial phase and the development of the information society, this issue has become less attractive for geography ${ }^{1}$. This is due to the

\footnotetext{
${ }^{1}$ Entering the post-industrial phase, in which the economic base are services, is determined on the basis of the increasing share of the service sectors and reducing this of the industry in the labour market. This mainly results from the ongoing automation and robotisation in industrial production; hence, part of the labour force in industrial
} 
fact that industry has gradually reduced its importance at the labour market and in the share of GDP to services.

Meanwhile, more and more modern industrial production is becoming the subject of international trade, contributing significantly to the activation of the labour market and increase in the financial resources of the population, which affects economic development. Also, in current conditions, entrepreneurs strongly influence the economic growth of countries, regions and local systems, and become the main contribution to stimulating the economy and recovery from the crisis. Progressive development requires increasingly more precise knowledge and improved research methods that allow for undertaking new problems referring to the current trends of development. This also refers to studies of new processes emerging in the geographical space. This requires assessment of existing research methods and development of new research models referring to the changing social, economic, cultural and natural conditions.

The above ideas are also reflected in the research in the field of industrial geography, evaluating and defining research directions in industrial geography (Dobrowolska, 1965a; Kortus, 1987; Stryjakiewicz, 1987, 1994, 2001), proposing new modelling approaches in order to organise and generalise the empirical facts (Zioło, 1980, 1988b, 1992, 1994a, 1994b, 1997, 2003), as well as deepening the content of empirical research (Misztal, Zioło, 1998). The assumption which should be at the methodological basis of geographical research holds that all the processes of socio-economic and cultural development happen in a specific place of the geographical space. They indicate the studies addressing the problem of industrial geography in the academic geography teacher training (Zioło, 1987a). Straszewicz (1987) treats industrial geography as the science and discipline of teaching at university level, Kortus (1987) draws attention to trends and research problems of industrial geography, Stryjakiewicz (1987) discusses research directions in industrial geography in Poland in years 1945-1980, while Pakuła and Zioło (1987) present the content of education in the field of industrial geography.

In these considerations, with reference to the system theory, it is assumed that the geographical space is a complex structure consisting of various elements and the relationships between them. This structure is distinguished by its natural, socio-economic and cultural space (Zioło, 1996, 1999, 2003). The elements of natural space include geological structure, climatic conditions, water conditions, relief, soils, vegetation and animal world. The structure of social space includes the spatial structure of agriculture, spatial structure of industry, communication network, the network of services and institutions, population distribution and diversity of demographic structures, settlement network, as well as capital and financial resources of the population. The cultural space includes material culture resources, spiritual resources and aspirations of the society, education, intellectual resources of the population, as well as social, political and cultural awareness.

production becomes redundant and goes into service sectors. Moreover, in the economically developed countries part of industrial production, especially requiring less-qualified professionals is transferred to less developed countries, characterised by lower labour costs. In Poland, however, the increase in the share of services in the structure of the labour market has mainly resulted from the decline of many companies in the period of management change system and, to a lesser extent, by increasing the potential of services. 
Functioning of the distinguished elements of the geographical space means there are various relationships in the form of active and passive linkages (Tab. 1). The delimited elements of the geographical space show a great diversity in terms of their potential, as well as spatial continuity or the lack of it. Depending on their properties, they form various surface, linear and point relations. Depending on the goals, their elements can be classified in terms of the size potential, certain properties or their functions. In light of these considerations, it can be assumed that the spatial structure of industry is part of a more complex system created by the socio-economic and geographical space (Zioło, 1997).

Tab. 1. Geographical space model

\begin{tabular}{|c|c|c|c|c|c|c|}
\hline & & & & & ographical s] & \\
\hline & & Elements of geographical space & & Natural & & Cultural \\
\hline & & & & $\mathrm{X}_{1}, \ldots, \mathrm{X}_{7}$ & $\mathrm{Y}_{1}, \ldots, \mathrm{Y}_{8}$ & $Z_{1}, \ldots, Z_{8}$ \\
\hline & & Geology & $X_{1}$ & & & \\
\hline & & Climate & $\mathrm{X}_{2}$ & & & \\
\hline & : & Water & $\mathrm{X}_{3}$ & & & \\
\hline & $\pi$ & Relief & $X_{4}$ & $\mathrm{X}_{\mathrm{ij}}^{\mathrm{x}}$ & $\mathrm{X}_{\mathrm{ij}}^{\mathrm{y}}$ & $\mathrm{X}_{\mathrm{ij}}^{\mathrm{z}}$ \\
\hline & 胥 & Soils & $\mathrm{X}_{5}$ & & & \\
\hline & & Vegetation & $X_{6}$ & & & \\
\hline & & Animals & $\mathrm{X}_{7}$ & & & \\
\hline & & Structure of farming & $\mathrm{Y}_{1}$ & & & \\
\hline & 怤 & Structure of industry & $\mathrm{Y}_{2}$ & & & \\
\hline : & $\begin{array}{l}m \\
.0\end{array}$ & Services & $\mathrm{Y}_{3}$ & & & \\
\hline$\frac{n}{\pi}$ & छี & Institutions & $\mathrm{Y}_{4}$ & $Y^{x}$ & $Y^{y}$ & $Y^{z}$ \\
\hline 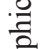 & ర్ & Transport and communication & $\mathrm{Y}_{5}$ & ${ }^{1}{ }_{i j}$ & $\mathrm{ij}$ & ${ }_{\mathrm{ij}}$ \\
\hline$\overline{\pi_{0}}$ & .0 & Demography & $\mathrm{Y}_{6}$ & & & \\
\hline ¿̊j & \begin{tabular}{l}
0 \\
\hdashline
\end{tabular} & Settlement pattern & $\mathrm{Y}_{7}$ & & & \\
\hline & & Capital resources & $\mathrm{Y}_{8}$ & & & \\
\hline & & Material culture & $Z_{1}$ & & & \\
\hline & & Spiritual culture & $\mathrm{Z}_{2}$ & & & \\
\hline & $\mathscr{J}_{\tilde{z}}$ & Aspirations of the society & $\mathrm{Z}_{3}$ & & & \\
\hline & $\frac{\pi}{\pi}$ & Education & $Z_{4}$ & & & \\
\hline & $\underline{\Xi}$ & Intelectual resources & $Z_{5}$ & $Z_{\mathrm{ij}}$ & $Z^{y}{ }_{i j}$ & $Z^{2}{ }^{i}$ \\
\hline & $\bar{E}$ & Social awareness & $\mathrm{Z}_{6}$ & & & \\
\hline & & Political awareness & $\mathrm{Z}_{7}$ & & & \\
\hline & & Cultural awareness & $Z_{8}$ & & & \\
\hline
\end{tabular}

Source: Zioło, 1996 
The differentiation of the geographical space is shaped by the increasing processes associated with the scientific, technological, technical and organisational progress, as well as the rules of economic development which set the direction and intensity of civilisation changes. At the same time, various elements of the geographical space and the relationships between them, offer different terms and conditions for activation of the processes of social, economic and cultural development.

A variety of conditions that occur in the geographical space (natural, socio-economic and cultural) are superimposed by the processes of economic development (micro-, meso-, macro-, mega-economic and global). Consequently, this leads to the differentiation of the level and dynamics of different-scale spatial systems, from the local level through a regional and national scale to the scale of individual continents and the world (Zioło, 2003). As a result, this evokes the mechanisms of spatial polarisation manifested by the differentiation of the level of development of different-scale spatial systems.

In the view of the presented assumptions, the theme of this discussion is the issue of the behaviour of an industrial enterprise in the development of the spatial structure of industry. In this paper the author refers to the earlier papers presenting the results of empirical studies on the development of the spatial structure of industry and determining the spatial structure of industry in the geographical space (Zioło, 1980, 1997, 2003, 2008), as well as a number of empirical studies carried out in the national academic centres (Misztal, Zioło, 1998) and presented in the subsequent publications of the Industrial Geography Commission of the Polish Geographical Society (Polskie Towarzystwo Geograficzne) ${ }^{2}$. Specific attention will be paid to the development of an industrial enterprise in the spatial structure of industry.

\section{AN INDUSTRIAL ENTERPRISE/PLANT}

The basic elements of the spatial structure of industry are industrial enterprises (plants) and the relationships between them. An industrial plant is an organisational unit, which is a single building or a complex of buildings located within the same area, equipped with means and objects of labour, and which is an independent organisational unit. This may be a company or an organisational part of an enterprise (plant, department, branch) used for manufacturing, services or marketing.

In the market economy an enterprise is an economic entity conducting production or service operations individually and at its own risk in order to achieve certain economic benefits. According to the microeconomic rules, the company's profit is considered as the main objective of the economic activity.

Industrial enterprises may be single-plant or multi-plant. Multi-plant companies have their production facilities, departments or branches in different locations of the industrial

2 Since 1987 the Industrial Geography Commission (Zioło, Rachwał, 2008) published 33 volumes, including 24 in a series of the Studies of the Industrial Geography Commission of the Polish Geographical Society, issued in cooperation with the Department of Entrepreneurship and Spatial Management of the Institute of Geography of the Pedagogical University of Cracow. 
space in a region, country or in the world. An integrating factor is the board assigning different objectives of their business. It performs a comprehensive settlement of the cost of business activities and defines the rules governing the distribution of achieved economic results.

The issue of an industrial enterprise within geographical research has been evolving. Ormicki (1934) treats an industrial plant as an element of landscape. Stepanov (1955), researching an industrial plant, attributes great importance to morphogenetic studies that aim to determine the relationship between the company and the surrounding economic and natural environment. Kuliński (1954) and Fierla $(1958,1988)$ propose researching industrial plants on the basis of technological, economic, techno-economic and location issues. Zawadzki (1962) defines an industrial plant as the basic spatial unit of industrial production. In an industrial plant, according to the author, the correlation between production and the space it impacts is focused. Moreover, the author defines a geographer's competence in solving the problems of spatial conditions of the creation and development of an industrial plant, interactions in the regional structure and its relation with environmental conditions.

In reference to these authors, Pakuła (1967) undertook the research of an industrial plant during field studies with the students of economic geography through a questionnaire, which was then adjusted to the research by Troc (1991) and Rachwał (2001a, 2008).

Fierla (1988) draws attention to the need to develop research on the location of industrial plants. The role of an industrial plant in the geographical space was pointed by Dobrowolska (1965a, 1965b, 1968), who assumed that it is an essential element of the spatial structure of industry and argued that the correct way of geographical thinking leads from the analysis of a workplace and production to the analysis of an industrial centre and district. Similar issues were undertaken in the framework of the former Committee for Research on Regions Undergoing Industrialisation of the Polish Academy of Sciences. In particular it concerned the socio-economic transformation in the hinterland of large industrial conglomerates (petrochemical in Płock, sulphuric in Tarnobrzeg3 ${ }^{3}$, energy in Turoszów and Konin, chemical in Puławy, copper in Legnica).

Partial summary of the research issues of an industrial plant was made in the framework of the Industrial Geography Commission of the Polish Geographical Society (Zioło, 1988a). Individual authors took up the issues of a functional model of an industrial plant functioning in the geographical space (Zioło, 1988b), location of industrial plants (Fierla, 1988), location of an industrial plant and the environment (Dziadek, 1988), employment in the industrial sector (Zioło, 1968, 1973, 1978a; Ohme, 1988; Soja, 1988), production and spatial relations of an industrial plant (Troc, 1988), links of technical and economic infrastructure (Makieła, 1988), technical and economic operation of power plants (Luchter, 1988), as well as the problems of an industrial enterprise in geography teaching (Piskorz, 1988; Rochnowski, 1988; Niżnik, 1988; Budzanowski, 1988).

In the first years of implementation of the rules of the market economy industrial plants faced the new economic and social situation (Zioło, 1994a). New research problems were

3 A significant share of research on industrialisation and its impact on social change was conducted by employees of the former Department of Economic Geography under the supervision of Professor Maria Dobrowolska (1965b, 1968; Zioło, 1978b). 
then undertaken focusing on the changing environment of industrial enterprises in the conditions of implementation of the rules of the market economy (Zioło, 1994b; Adamczak, 1994; Misztal, 1994), changes in the spatial behaviour of enterprises (Parysek, 1994) and privatisation (Matykowski, Szulc, 1994; Kozysa, Miszczuk, Żuk, 1994; Tobolska, 1994).

The issue under discussion was continued during the functioning of the market economy (Zioło, 2001a, 2008) and related to the behaviour of different types of enterprises (Musielak, 2001; Rydz, Jażewicz, 2001; Rachwał, 2000a, 2000b, 2001b, 2002, 2003b; Czapliński, 2008; Kostrubiec, 2006; Makieła, 2001; Matykowski, Tobolska, 2009; Śleszyński, 2007; Tobolska, Matykowski, 2006), functioning of an enterprise in the regional structure (Zioło, 2011), and revitalisation processes in post-industrial areas (Domański, 2001a; Czepczyński, 2001; Kopeć, 2009).

In view of the opening of the Polish economy into the world the undertaken research themes also included an analysis of the impact of foreign capital on the structure of the domestic industry (Domański, 2001b), as well as the impact of the global processes on industrial enterprises (Makieła, 1988, 2001; Śleszyński, 2002, 2008; Rachwał, 2003a). Changing behaviour of industrial enterprises in the economic crisis were also indicated (Rachwał, 2011; Wójtowicz, 2009a, 2009b, 2011; Zioło, 2011).

Implementation of the rules of the market economy and opening of the national companies to the world and moving the society into the information phase of development requires the pursuit of knowledge of the developmental processes of multinational corporations. They mainly affect the intensification of the process of internationalisation of industrial production, the implementation of production of modern products and intensifying globalisation.

This was reflected by the research undertaken on the functioning and shaping of global industrial corporations (Zioło, 2001b, 2006, 2009), especially IT companies (Wajda, 2003, 2006; Wajda, Zoric-Wołek, 2003; Wójtowicz, 2009; Kilar, 2009a, 2009b, 2010, 2011; Stryjakiewicz, 2009; Świdurska, 2009) and the automotive industry, which was regarded as an important factor of expanding economic development (Wójtowicz, 2011; Lizak, 2009a, 2009b).

\section{SPATIAL STRUCTURE OF INDUSTRY}

Following the model of the geographical space, it is assumed that the spatial structure of industry includes a variety of companies and factories, as well as active and passive relationships between them (Zioło, 1997). On the basis of economics, Secomski (1956) and Florecie (1965), giving examples of various types of industrial structures, assume that the basic elements of the spatial structure of industry are industrial plants and all the relations between them which describe their production, economic and social ties.

The term "the spatial structure of industry" was introduced to the national geographical literature by Dziewoński (1946) while undertaking the issues shaping the production complex in the location theory and the practice of economic planning. Reflecting on this concept 
Kukliński (1954) finds that it is superior to the concepts of "the distribution of industry" and "the location of industry".

It is assumed that the spatial structure of industry is one of the objective socio-economic spaces, characterised by a set of industrial, commercial and service enterprises (companies). They are characterised by a different economic potential, quality of production and services, and specific economic and social features (Zioło, 1970, 1973; Misztal, 1970). They are formed by the intensity of the technical and economic forces that enable spatial and production relations (Pakuła, 1965, 1973), as well as capital-financial, institutional and organisational relations occurring at different levels of spatial systems. The spatial structure of industry is characterised by varying attractiveness for the location and clustering of companies whose presence shapes the various forms of spatial concentration of industry.

\section{MEASURING THE POTENTIAL OF INDUSTRIAL ENTERPRISES}

Industrial companies are not homogeneous elements but show very large diversity in terms of their economic potential, classification to different sectors, specific functions they perform in the production process, as well as in the spatial structure of industry and in the geographical space. A large variety of industrial enterprises in terms of their technical and economic potential are illustrated by the following:

Production and service capacity, measured by the size and value of production, the value of the sales and assets, the market value etc.;

Technical capacity, measured by the power of the installed generating and receiving equipment, energy consumption (electricity, gas, heat), the level of modernity of the technological equipment;

Efficiency of production and service capacity, measured by labour productivity, capital and energy intensity of production, employment infrastructure;

Size of the labour market, measured by the number of employed workers and their demographic and socio-professional structures, as well as the percentage of local workers and commuters.

Thus, economic and technical potential of enterprises can be expressed by a number of variables that are significant in terms of the research aim. For example, analysing the industrial enterprises from the labour market angle, an important measure is the number of employees, from the settlement angle an important measure is the area occupied by the company, while from the side of its spatial functions an important measure is the extent and intensity of the active and passive linkages.

A particularly important role in the assessment of an enterprise is played by the features determining the efficiency characteristics of property and labour, which greatly affect the cost of production, the competitiveness of the products and, consequently, the financial results of the company. Analysing a company in light of these characteristics (indicators), we get a different picture of the branch and spatial structure of industry (Zioło, 1973, 2011). 
Therefore, to determine the potential of industry, a synthetic measure is often assumed to determine the potential of the company, but also to indicate which of the empirical measures, and to what extent, affect the value of the synthetic measure (Zioło, 1972, 1976).

Depending on the type of production, industrial enterprises represent different industry sectors, which are determined on the basis of the accepted principles for the classification of the national economy, including industrial activities. Changes introduced to the classification of the national economy often hinder the analysis of structural changes in industry and the national economy in the long term; hence the need to give estimates to get a relatively comparable picture of the changes.

In multi-plant companies individual firms may represent different departments and play different roles in the production of final products. They can make the final product or some of its components such as preparation of raw materials, energy supply, producing components within the cooperative relations, assembling the components supplied from other companies, provide financial turnover and engaged in marketing and sales. Concentration of many departments in a company that meets a variety of functions is due to economic calculation. Therefore, companies often outsource the execution of these tasks to outside companies that may be more favourable to them than keeping them in the structure of the company.

\section{FUNCTIONS OF INDUSTRIAL ENTERPRISES IN THE SPATIAL STRUCTURE OF INDUSTRY}

From the point of view of spatial relationships, particularly important in the geographical studies are enterprise functions in the spatial structure of industry and in the geographical space. Given the importance of enterprises in the economic space in terms of their functions, companies can be divided into local, supra-local, regional, national, international and global.

Enterprises of local functions work mainly for the particular individual settlement unit (village or gmina, such as bakeries, bottling water, repair of motor vehicles). The range of their impact is limited to a relatively small area and the size of their production and services relate to the capacity of the local market. They can be represented by individual plants, which have a monopoly on certain activities on the small market, or plants having the same production functions. Then they are shaped either on the basis of the rules of competition, or on the basis of a gentlemen's agreement of entrepreneurs who divide the local market between them, thus limiting the competition among one another. Companies of local functions have a relatively small technical and economic potential; most of them are family businesses that create the labour market for a relatively small number of employees. Plants of this type are common in the spatial structure of industry and show a uniform distribution. They refer to the demographic potential that creates a specified-size market for their products. In contrast, the relationship of raw materials and supplies can have a much wider range of influence (regional) and technical ties related to the supply of machinery and equipment and spare parts may have the national or even international range. Location and size of business establishments in this category relate strongly to the size of the local market capacity. 
Companies of supra-local functions are similarly shaped, but the extent of their impact is larger and covers an area of several gminas, a poviat or several poviats. The nature of their business means the local market is too small for them and they must seek markets in a wider area. Among them, besides the market location, there are also facilities of locations tied to the existence of mineral raw materials (china clay, sand pit, quarry). Their market is created not only by people, but also other companies with whom they cooperate, e.g. in the field of cooperative relations.

Enterprises of the regional functions limit their activities to the size of the voivodeship market and often to the markets of the neighbouring voivodeships. As a rule, they have a greater techno-economic potential, require specialised equipment and repair service. Regional market may pose different requirements for the products offered, from the very common to the unique products. They are characterised by a greater degree of spatial concentration of economic activity and occur mainly in the larger cities. Among them there are also companies with connected locations or those requiring special locations because of the nature of their business (e.g. the presence of mineral or forest resources, or adverse affects on the natural and living conditions of the population).

National functions are represented by the companies operating on the domestic market. They occur sporadically within the spatial structure, especially in larger cities or in the immediate vicinity of the occurrence of raw materials (minerals, agriculture). The size of their technical and economic potential refers to the capacity of the domestic market.

International functions are represented by the companies operating for the needs of the market in several countries, while global functions are represented by the corporations which have a global range. They are characterised by a complex internal structure controlled by the board located predominantly in highly developed countries (Kilar, 2009a, 2010, 2011; Wajda, 2003, 2006; Wajda, Zoric-Wołek, 2003; Zioło, 2001b, 2003, 2006, 2011). These enterprises are characterised by high economic potential and play a significant role in the economy of the world ${ }^{4}$. They conduct production or service activity through branches located throughout most of the world, tailored to the needs of a particular market ${ }^{5}$. These companies create different types of relationships with other companies in the global economic space, such as in the following areas: raw materials supply, the links in the manufacture of certain semi-finished products, components or assembly of finished products, as well as links in terms of energy supplies and others. Enterprises of this type can also affect the economic activation of other countries, including through direct foreign investment and the use of the

${ }^{4}$ In 2012, the economic potential of the global corporation General Electric, which includes branches representing various sectors of economic activity, including industrial activity, was as follows: sales - 147.4 billion USD, assets -685.3 billion USD, market value -243.7 billion USD, profit - 13.6 billion USD. The economic potential of the largest corporation Exxon Mobil, representing the fuels sector, was as follows: sales -420.7 billion USD, market value -400.4 billion USD, assets -333.8 billion USD, profits -44.9 billion USD. The economic potential of the Volkswagen Group included: sales -254.0 billion USD, assets -408.2 billion USD, market value -94.4 billion USD, profits - 28.6 billion USD (Forbes, 2013).

5 In 2003, the corporation Nokia had 116 branches located in 53 countries, the largest number in the United States (17) as well as Brazil, the UK, China (7 each) and India (3), while MBI had its branches located in 130 countries (Wajda, 2006; Wajda, Zoric-Wołek, 2003). 
facilities such as special economic zones (Domański, 2001a; Rachwał, 2003a, 2007, 2013; Rachwał, Wiedermann, 2008). This type of enterprises is also represented by those which refer to the unique location in the world's natural resources, such as rare earth metals ${ }^{6}$ and non-ferrous metal ores, which are necessary for the production of innovative products. The manufactures producing at relatively low cost may also be included in this category, for example, the products offered by Chinese companies.

Range and capacity of market areas of particular types of enterprises are subject to change. This stems from the increase or decrease of the financial resources of the population and institutions, decisions resulting from socio-economic policy of the state or other needs resulting from the necessity of public procurement (e.g. defence, the implementation of new management methods, and stimulating innovation in the economy). These companies also undergo spatial expansion in search for new markets, which is mainly conducive to competitiveness in terms of prices and quality of products. As a result, different types of enterprises adjust their production and service scale to the capacity of the market areas in order to achieve maximum economic benefits now and in the foreseeable future.

Industrial enterprises in the economic area are not isolated elements; certain relationships occur between them, expressed by the spatial and production linkages (Tab. 2). Generally, there are three types of the relationships between them. The first type is represented by the close linkages between the two enterprises of the same type, namely local [ $\left.\mathrm{x}_{11}\right]$, supra-local $\left[\mathrm{x}_{22}\right]$, regional $\left[\mathrm{x}_{33}\right]$, national $\left[\mathrm{x}_{44}\right]$, international $\left[\mathrm{x}_{55}\right]$ and global $\left[\mathrm{x}_{66}\right]$.

The second type active linkages are shown in the table rows. They illustrate the impact of a given type of business on other types of businesses, such as the impact of local enterprises on the supra-local ones is illustrated by the relationship $\left[\mathrm{x}_{12}\right]$, on the regional ones by $\left[\mathrm{x}_{13}\right]$ and on the national ones by $\left[\mathrm{x}_{14}\right]$; the impact of national enterprises on the regional ones by $\left[\mathrm{x}_{43}\right]$ and on the international ones by $\left[\mathrm{x}_{45}\right]$, or the impact of global industries on the local ones by $\left[\mathrm{x}_{61}\right]$, on the regional ones by $\left[\mathrm{x}_{63}\right]$ and on the national ones by $\left[\mathrm{x}_{64}\right]$ etc. The second type passive relationships are shown in the columns of the table. They illustrate the impact of different types of companies on a particular other type. For instance, the impact on a national enterprise is represented by relations from $\left[\mathrm{x}_{13}\right]$ to $\left[\mathrm{x}_{63}\right]$, and on the international company by relations from $\left[\mathrm{x}_{16}\right]$ to $\left[\mathrm{x}_{65}\right]$. The values $\left[\mathrm{x}_{43}\right]$ or $\left[\mathrm{x}_{34}\right]$ are not equal; the earlier shows the impact of international companies on national companies, while the latter one the reverse relationships, i.e. the impact of national enterprises on multinational ones. These relationships can be related to individual companies or groups representing the same type. Certain relations can lead to an intensification of relations and have a beneficial effect on increasing the economic activity of the enterprise, or maintain a constant level of the existing relationships, which results in the stagnation of a given enterprise; or a weakening of the existing relations such as in times of crisis, which leads to the recession of the current activity.

${ }^{6}$ Rare earth metals include 17 elements, such as terbium, lanthanum, neodymium, lutetium and cerium. They are widely used in high-tech industries, such as production of catalytic converters, motors for electric vehicles, flat screens, hard drives, camera lenses and medical devices. About $97 \%$ of supplies to the world market come from China. 
Therefore, learning these relations poses important reasons for making strategic decisions on the business of the company.

$T a b .2$. Functional linkages between enterprises within the socio-economic space

\begin{tabular}{|c|c|c|c|c|c|c|c|}
\hline \multicolumn{2}{|c|}{$\begin{array}{c}\text { Types of } \\
\text { enterprises }\end{array}$} & local & supra-local & regional & national & international & global \\
\cline { 3 - 8 } & $\mathrm{X}_{1}$ & $\mathrm{X}_{2}$ & $\mathrm{X}_{3}$ & $\mathrm{X}_{4}$ & $\mathrm{X}_{5}$ & $\mathrm{X}_{6}$ \\
\hline local & $\mathrm{X}_{1}$ & $\mathrm{X}_{11}$ & $\mathrm{X}_{12}$ & $\mathrm{X}_{13}$ & $\mathrm{X}_{14}$ & $\mathrm{X}_{15}$ & $\mathrm{X}_{16}$ \\
\hline supra-local & $\mathrm{X}_{2}$ & $\mathrm{X}_{21}$ & $\mathrm{X}_{22}$ & $\mathrm{X}_{23}$ & $\mathrm{X}_{24}$ & $\mathrm{X}_{25}$ & $\mathrm{X}_{26}$ \\
\hline regional & $\mathrm{X}_{3}$ & $\mathrm{X}_{31}$ & $\mathrm{X}_{32}$ & $\mathrm{X}_{33}$ & $\mathrm{X}_{34}$ & $\mathrm{X}_{35}$ & $\mathrm{X}_{36}$ \\
\hline national & $\mathrm{X}_{4}$ & $\mathrm{X}_{41}$ & $\mathrm{X}_{42}$ & $\mathrm{X}_{43}$ & $\mathrm{X}_{44}$ & $\mathrm{X}_{45}$ & $\mathrm{X}_{46}$ \\
\hline international & $\mathrm{X}_{5}$ & $\mathrm{X}_{51}$ & $\mathrm{X}_{52}$ & $\mathrm{X}_{53}$ & $\mathrm{X}_{54}$ & $\mathrm{X}_{55}$ & $\mathrm{X}_{56}$ \\
\hline global & $\mathrm{X}_{6}$ & $\mathrm{X}_{61}$ & $\mathrm{X}_{62}$ & $\mathrm{X}_{63}$ & $\mathrm{X}_{64}$ & $\mathrm{X}_{65}$ & $\mathrm{X}_{66}$ \\
\hline
\end{tabular}

Source: own compilation

\section{BALANCE OF SPATIAL LINKAGES IN ENTERPRISE ACTIVITIES}

Comparison of supply and sales allows balancing the spatial relationships of a given enterprise (Zioło, 1978a, 1978b, 1982). On this basis, we can identify the following areas:

Exclusively sales areas, where the products are directed, in the absence of their linkages in the supply sector;

Dominated by sales over the value of the supply;

Of a similar share of the sales and supply;

Of a larger share of supply over the value of sales;

Exclusive supply areas at the absence of sales.

Assessment of spatial relations allows determining the degree of dependence of the company on the surroundings. In the process of transformation the market and supply environment may create more favourable or less favourable conditions for the possibility of increased linkages. Of great importance in this respect is also the quality of political relations between countries, which can stimulate or limit the possibilities of exchange.

\section{CONCLUDing REMARKS}

The processes of socio-economic development take place at the different-scale spatial systems within the geographical space (from the local through the national to the global level). The geographical space covers a diverse natural space, various potential of the socio-economic and cultural space, as well as active and passive relations that occur between their elements. 
The structure of the socio-economic space contains the spatial structure of the industry, consisting of functionally diverse production and service companies, and the spatial relationships that exist between them. The diverse conditions offered by the spatial structure of industry and the geographical space create specific opportunities of location and economic activity of industrial enterprises. Enterprises develop in specific spatial conditions under given economic rules. They lead to increasing internationalisation of production and increasing globalisation. In this approach, an industrial enterprise is a basic element of the spatial structure of industry and the socio-economic space, as well as the geographical space.

An important role in this complex process is played by the research in the industrial geography. They lead to the understanding of the functioning and development opportunities for enterprises, whose primary goal is to maximise economic effects. They make it possible for the functionally diverse enterprises to learn spatial conditions and patterns of developmental processes of enterprises. The achieved results are important reasons for taking rational decisions in building a developmental strategy in which an important role is played by passive and active spatial relationships. They lead to defining market size, assessment of its quality and scope for a deeper and wider development, which seriously affects the economic activity of enterprises.

\section{References}

Adamczak, Z. (1994). Funkcjonowanie zakładów przemysłu mięsnego w nowych warunkach społeczno-ekonomicznych (na przykładzie zakładów Mięsnych w Krotoszynie), In: Z. Zioło (ed.), Funkcjonowanie przedsiębiorstw przemystowych $w$ zmieniajacych się warunkach gospodarowania. Materiały i Sprawozdania COMSN, 29, Kraków: Wydawnictwo Naukowe WSP, 39-147.

Budzanowski, J. (1988). Znaczenie zakładu przemysłowego w nauczaniu geografii przemysłu na tle zmieniających się orientacji filozoficzno-metodologicznych. In: Z. Zioło (ed.), Zakład przemystowy w akademickim ksztatceniu nauczycieli geografii. Materiały i Sprawozdania COMSN, 16, Kraków: Wydawnictwo Naukowe WSP, 32-135.

Czapliński, P. (2008). Problematyka badawcza przemysłu w geografii na tle nauk ekonomicznych. Prace Komisji Geografii Przemystu Polskiego Towarzystwa Geograficznego, 11, 46-52.

Czepczyński, M. (2001). Przemiany zagospodarowania terenów portowo-przemysłowych aglomeracji Trójmiasta. Prace Komisji Geografii Przemystu Polskiego Towarzystwa Geograficznego, 3, 93-97.

Dobrowolska, M. (1965a). Tendencje rozwojowe geografii przemysłu w okresie XX-lecia Polski Ludowej. Przeglad Geograficzny, 4.

Dobrowolska, M. (1965b). Zeszyty Badań Rejonów Uprzemysławianych, 13. Komitet Badań Rejonów Uprzemysławianych przy Prezydium PAN.

Dobrowolska, M. (red.) (1968). Demograficzno-osadnicze problemy w tarnobrzeskim Rejonie Uprzemysławianym. Zeszyty Badań Rejonów Uprzemysławianych, 29. KBRU przy Prezydium PAN.

Domański, B. (2001a). Przekształcenia terenów poprzemysłowych w województwie śląskim i małopolskim. Prace Komisji Geografii Przemystu Polskiego Towarzystwa Geograficznego, 3, 51-59.

Domański, B. (2001b). Kapitał zagraniczny w przemyśle Polski. Kraków: Uniwersytet Jagielloński, Instytut Geografii i Gospodarki Przestrzennej. 
Dziadek, S. (1988). Lokalizacja zakładu przemysłowego a ochrona środowiska przyrodniczego. In: Z. Zioło (ed.), Zakład przemystowy w akademickim kształceniu nauczycieli geografii. Materiały i Sprawozdania COMSN, 16, Kraków: Wydawnictwo Naukowe WSP, 46-56.

Dziewoński, K. (1946). Zagadnienie zespołu produkcyjnego w teorii lokalizacji i praktyce planowania. Ekonomista, 3, 106-123.

Fierla, I. (1958). Zakład przemysłowy jako przedmiot badań geograficzno-ekonomicznych. Zeszyty Naukowe SGiS, 7.

Fierla, I. (1988). Problemy lokalizacji zakładów przemysłowych. In: Z. Zioło (ed.), Zakład przemystowy w akademickim ksztatceniu nauczycieli geografii. Materiały i Sprawozdania COMSN, 16, Kraków: Wydawnictwo Naukowe WSP, 25-45.

Florecie, P.S. (1965). Brytyjski i amerykański system przesyłowy. Warszawa: PWE.

Kilar, W. (2009a). Koncentracja światowych firm informatycznych. Prace Komisji Geografii Przemystu Polskiego Towarzystwa Geograficznego, 12, 97-108.

Kilar, W. (2009b). Zróżnicowanie potencjału ekonomicznego światowych korporacji informatycznych. Prace Komisji Geografii Przemystu Polskiego Towarzystwa Geograficznego, 13, 110-121.

Kilar, W. (2010). Procesy kształtowania się korporacji Ericsson. Prace Komisji Geografii Przemystu Polskiego Towarzystwa Geograficznego, 16, 137-152.

Kilar, W. (2011). Wpływ kryzysu na funkcjonowanie korporacji Panasonic. Prace Komisji Geografii Przemystu Polskiego Towarzystwa Geograficznego, 17, 187-196.

Kortus, B. (1987). Aktualne kierunki i problemy badawcze geografii przemysłu. In: Z. Zioło (ed.), Geografia przemystu w akademickim kształceniu nauczycieli. Materiały i Sprawozdania COMSN, 14, Kraków: Wydawnictwo Naukowe WSP, 14-21.

Kopeć, M. (2009). Rewitalizacja przemysłowych miast angielskich na przykładzie Barnsley. Prace Komisji Geografii Przemystu Polskiego Towarzystwa Geograficznego, 12, 183-193.

Kostrubiec, B. (2006). Delokalizacja przedsiębiorstw - przejaw światowej samoregulacji. Prace Komisji Geografii Przemystu Polskiego Towarzystwa Geograficznego, 8, 37-46.

Kozysa, J., Miszczuk, A., Żuk, K. (1994). Procesy prywatyzacji przedsiębiorstw przemysłowych Lubelszczyzny. In: Z. Zioło (ed.), Funkcjonowanie przedsiębiorstw przemysłowych w zmieniajacych się warunkach gospodarowania. Materiały i Sprawozdania COMSN, Kraków: Wydawnictwo Naukowe WSP, 86-95.

Kukliński, A. (1954). Zakład przemysłowy w akademickim nauczaniu geografii. Czasopismo Geograficzne, 4.

Lizak, P. (2009a). Kształtowanie się przemysłu samochodów osobowych krajach Europy Środkowej. Prace Komisji Geografii Przemystu Polskiego Towarzystwa Geograficznego, 14, 50-56.

Lizak, P. (2009b). Wpływ koncernu Fiat na kształtowanie się przemysłu samochodów osobowych, w Polsce. Prace Komisji Geografii Przemystu Polskiego Towarzystwa Geograficznego, 12, 79 86.

Luchter, L. (1988). Wybrane problemy techniczno-ekonomiczne elektrowni i przestrzenne funkcjonowanie elektrowni systemowych. In: Z. Zioło (ed.), Zakład przemysłowy w akademickim kształceniu nauczycieli geografii, Materiały i Sprawozdania COMSN, 16, Kraków: Wydawnictwo Naukowe WSP.

Makieła, Z. (1988). Powiązania zakładu przemysłowego z elementami infrastruktury technicznej. Zakład przemysłowy w akademickim kształceniu nauczycieli geografii, COMSN, Materiały i Sprawozdania, 16, 92-97.

Makieła, Z. (2001). Przekształcenia Skawińskich Zakładów Koncentratów Spożywczych jako przejaw procesu globalizacji. Prace Komisji Geografii Przemystu Polskiego Towarzystwa Geograficznego, 3, 149-154.

Matykowski, R., Tobolska, A. (2009). Funkcjonowanie zakładów przemysłowych w XXI wieku na przykładzie Swedwood Poland i Volkswagen Motor Polska S.A. Prace Komisji Geografii Przemystu Polskiego Towarzystwa Geograficznego, 14, 65-75. 
Matykowski, R., Szulc, R. (1994). Przekształcenia własnościowe przedsiębiorstw państwowych w województwie poznańskim. In: Z. Zioło (ed.), Funkcjonowanie przedsiębiorstw przemysłowych $w$ zmieniajacych się warunkach gospodarowania. Materiały i Sprawozdania COMSN, 29, Kraków: Wydawnictwo Naukowe WSP, 76-85.

Misztal, S. (1970). Przemiany w strukturze przestrzennej przemysłu na ziemiach polskich w latach 1860-1965. Studia Komitetu Przestrzennego Zagospodarowania PAN, 21.

Misztal, S. (1994). Wpływ wielkości zakładów i przedsiębiorstw przemysłowych na ich funkcjonowanie w okresie przejściowym do gospodarki rynkowej. In: Z. Zioło (ed.), Funkcjonowanie przedsiębiorstw przemystowych $w$ zmieniajacych się warunkach gospodarowania. Materiały i Sprawozdania COMSN, 29, Kraków: Wydawnictwo Naukowe WSP, 164-171.

Misztal, S., Zioło Z. (1998). Dorobek polskiej geografii przemystu. Komisja Geografii Przemysłu Polskiego Towarzystwa Geograficznego, Instytut Geografii Wyższej Szkoły Pedagogicznej im. Komisji Edukacji Narodowej w Krakowie. Warszawa-Kraków: Wyd. Krakowskiego Oddziału PAN.

Musielak, J. (2001). Procesy restrukturyzacji w przemyśle okrętowym (na przykładzie Stoczni Szczecińskiej S.A.).Prace Komisji Geografii PrzemystuPolskiego Towarzystwa Geograficznego, 3, $155-156$.

Niżnik, A.M. (1988). Zespół Górniczo-Energetyczny „Bełchatów” jako obiekt badań naukowych i wycieczek dydaktycznych. In: Z. Zioło (ed.), Zakład przemysłowy w akademickim kształceniu nauczycieli geografii. Materiały i Sprawozdania COMSN, 16, Kraków: Wydawnictwo Naukowe WSP, 127-131.

Ohme, J. (1988). Problematyka siły roboczej w zakładzie przemysłowym. In: Z. Zioło (ed.), Zakład przemystowy $w$ akademickim kształceniu nauczycieli geografii. Materiały i Sprawozdania COMSN, 16, Kraków: Wydawnictwo Naukowe WSP, str. 57-65.

Ormicki, W. (1934). Zakład przemysłowy przedmiotem badań geograficznych. Wiadomości Geograficzne, 12, 18.

Pakuła, L. (1965). Kształtowanie się i struktura Zachodnio-Krakowskiego Kompleksu Przemysłowego. Biuletyn Komitetu Przestrzennego Zagospodarowania PAN, Seria A, 2.

Pakuła, L. (1967). Uwagi o prowadzeniu ćwiczeń terenowych z geografii przemysłu. Prace z Dydaktyki Szkoty Wyższej, 4.

Pakuła, L. (1973). Procesy aglomeracyjne i integracyjne przemystu w obszaru Górnośląskiego Okręgu Przemystowego. Prace monograficzne WSP w Krakowie, 9.

Pakuła, L., Zioło, Z. (1987). Treści kształcenia w zakresie geografii przemysłu na wykładach. In: Z. Zioło (ed.), Geografia przemystu w akademickim kształceniu nauczycieli. Materiały i Sprawozdania COMSN, 14, Kraków: Wydawnictwo Naukowe WSP, 58-64.

Parysek, J.J. (1994). Zachowania przestrzenne przedsiębiorstw przemysłowych w nowych warunkach społeczno-ustrojowych (na przykładzie Swarzędzkich Fabryk Mebli S.A.). In: Z. Zioło (ed.), Funkcjonowania przedsiębiorstw przemystowych zmieniajacych się warunkach gospodarowania. Materiały i Sprawozdania COMSN, 29, Kraków: Wydawnictwo Naukowe WSP, 22-30.

Piskorz, S. (1988). Tematyka zakładu przemysłowego w nauczaniu geografii w szkole podstawowej i średniej. In: Z. Zioło (ed.), Zakład przemysłowy w akademickim kształceniu nauczycieli geografii. Materiały i Sprawozdania COMSN, 16, Kraków: Wydawnictwo Naukowe, 116-126.

Rachwał, T. (2000a). Zmiany funkcjonowania Zakładów Przemysłu Cukierniczego „San” S.A. w Jarosławiu pod wpływem inwestycji zagranicznych. In: Z. Zioło (ed.), Działalność człowieka i jego środowisko. Kraków: Wydawnictwo Naukowe AP, 323-336.

Rachwał, T. (2000b). Wpływ inwestycji zagranicznych na zmiany w funkcjonowaniu Huty Szkła Jarosław S.A. w procesie transformacji gospodarczej. Rocznik Naukowo-Dydaktyczny AP w Krakowie, 209, Prace Geograficzne XVIII, 63-72.

Rachwał, T. (2001a). Problematyka kwestionariusza do badań funkcjonowania przedsiębiorstwa przemysłowego w okresie transformacji systemu gospodarowania. Prace Komisji Geografii Przemystu Polskiego Towarzystwa Geograficznego, 2, 49-57. 
Rachwał, T. (2001b). Proces restrukturyzacji Zakładów Mięsnych „Nisko” S.A. jako potencjalny czynnik aktywizacji rolniczej bazy surowcowej północnej części województwa podkarpackiego. Prace Komisji Geografii Przemystu Polskiego Towarzystwa Geograficznego, 3, 181-189.

Rachwał, T. (2002). Proces restrukturyzacji przedsiębiorstw przemysłowych Polski PołudniowoWschodniej (na wybranych przykładach). Prace Komisji Geografii Przemystu Polskiego Towarzystwa Geograficznego, 4, 79-88.

Rachwał, T. (2003a). Globalne uwarunkowania restrukturyzacji przedsiębiorstw Polski PołudniowoWschodniej. Prace Komisji Geografii Przemystu Polskiego Towarzystwa Geograficznego, 6, $129-138$.

Rachwał, T. (2003b). Funkcjonowanie Krakowskich Zakładów Elektronicznych „Telpod” w świetle przemian w polskim przemyśle elektronicznym. Prace Komisji Geografii Przemystu Polskiego Towarzystwa Geograficznego, 3, 167-180.

Rachwał, T. (2007). Zmiany powiązań przestrzennych przedsiębiorstw przemysłowych Polski Południowo-Wschodniej w latach transformacji systemu gospodarowania. In: J. Lach, M. Borowiec, T. Rachwał (eds.), Procesy transformacji społeczno-ekonomicznych i przyrodniczych struktur przestrzennych. Ksiega Jubileuszowa dedykowana Profesorowi Zbigniewowi Zioło. Kraków: Wydawnictwo Naukowe AP w Krakowie, 325-351.

Rachwał, T. (2008). Problematyka badawcza funkcjonowania przedsiębiorstw przemysłowych. Prace Komisji Geografii Przemystu Polskiego Towarzystwa Geograficznego, 11, 53-85.

Rachwał, T. (2011). Wpływ kryzysu na zmiany produkcji przemysłowej w Polsce. Prace Komisji Geografii Przemystu Polskiego Towarzystwa Geograficznego, 17, 99-113.

Rachwał, T. (2013). Rola przedsiębiorstw przemysłowych w rozwoju gospodarki opartej na wiedzy. Prace Komisji Geografii Przemystu Polskiego Towarzystwa Geograficznego, 21, 189-211.

Rachwał, T., Wiedermann, K. (2008). Multiplier effects in regional development: The case of the motor vehicle industry in Silesian voivodeship (Poland). Questiones Geographicae, 27B/1, 67-80.

Rochnowski, H. (1988). Organizacja i rola naukowych wycieczek do zakładów przemysłowych w nauczaniu geografii. In:Z. Zioło (ed.), Zakład przemysłowy w akademickim kształceniu nauczycieli geografii. COMSN, Materiaty i sprawozdania, 16, 108-115.

Rydz, E., Jażewicz, I. (2001). Przemiany strukturalne przemysłu na przykładzie małych miast Pomorza Środkowego. Prace Komisji Geografii Przemystu Polskiego Towarzystwa Geograficznego, 3, 71-86.

Secomski, K. (1956). Wstęp do teorii rozmieszczenia sit wytwórczych. Warszawa: PWE.

Soja, M. (1988). Problemy zatrudnienia w zakładzie przemysłowym. In:Z. Zioło (ed.), Zakład przemysłowy w akademickim kształceniu nauczycieli geografii. Materiały i Sprawozdania COMSN, 16, Kraków: Wydawnictwo Naukowe WSP, 66-78.

Stiepanow, P. (1955). Metodyka badań przedsiębiorstwa przemysłowego i przemysłu regionu. Geografia przemysłu ZSRR. Przegląd Zagranicznej Literatury Geograficznej, 4.

Straszewicz, L. (1987). Geografia przemysłu jako nauka i dyscyplina nauczania. In: Z. Zioło (ed.), Geografia przemystu w akademickim kształceniu nauczycieli. Materiały i Sprawozdania COMSN, 14, Kraków: Wydawnictwo Naukowe WSP, 8-13.

Stryjakiewicz, T. (1987). Kierunki badawcze geografii przemysłu w Polsce w latach 1945-1980. In: Z. Zioło (ed.), Geografia przemystu w akademickim ksztatceniu nauczycieli. Materiały i Sprawozdania COMSN, 14, Kraków: Wydawnictwo Naukowe WSP, 22-46.

Stryjakiewicz, T. (1994). Problematyka przedsiębiorstwa przemysłowego w pracach Komisji Przemian Przemysłu i Komisji Organizacji Przestrzeni Przemysłowej Międzynarodowej Unii Geograficznej. In: Z. Zioło (ed.), Funkcjonowanie przedsiębiorstw przemysłowych $w$ zmieniających się warunkach gospodarowania. Materiały i Sprawozdania COMSN, 29, Kraków: Wydawnictwo Naukowe WSP 50-56.

Stryjakiewicz, T. (2001). Orientacje teoretyczno-metodologiczne w geografii przemysłu a transformacja gospodarki. Prace Komisji Geografii Przemystu Polskiego Towarzystwa Geograficznego, 3, $13-27$. 
Stryjakiewicz, T. (2009). Lokalizacja firm i zachowania przestrzenne pracowników sektora informatycznego (na przykładzie poznańskiego obszaru metropolitalnego). Prace Komisji Geografii Przemystu Polskiego Towarzystwa Geograficznego, 13, 21-33.

Śleszyński, P. (2002). Struktura i koncentracja przestrzenna siedzib ważniejszych przedsiębiorstw w Warszawie w 1999 r. Prace Komisji Geografii Przemystu Polskiego Towarzystwa Geograficznego, 4, 89-114.

Śleszyński, P. (2007). Gospodarcze funkcje kontrolne w przestrzeni Polski. Prace Geograficzne, 213. Warszawa: Instytut Geografii i Przestrzennego Zagospodarowania im. S. Leszczyckiego.

Śleszyński, P. (2008). Duże przedsiębiorstwa w strukturze przestrzennej największych polskich miast. Prace Geograficzne, 217. Warszawa: Instytut Geografii i Przestrzennego Zagospodarowania im. S. Leszczyckiego.

Świdurska, A. (2009). Kształtowanie się przemysłu wysokiej techniki w Polsce. Prace Komisji Geografii Przemystu Polskiego Towarzystwa Geograficznego, 13, 56-67.

Tobolska, A. (1994). Funkcjonowanie „Amino” S.A. w zmieniających się warunkach ekonomicznych i społecznych. In: Z. Zioło (ed.), Funkcjonowanie przedsiębiorstw przemystowych $w$ zmieniajacych się warunkach gospodarowania. Materiały i Sprawozdania COMSN, 29, Kraków: Wydawnictwo Naukowe WSP, 158-163.

Tobolska, A., Matkowski, R. (2006). Działalność przemysłowa w warunkach wzrastającej internacjonalizacji i globalizacji na przykładzie wybranych produktów. Prace Komisji Geografii Przemystu Polskiego Towarzystwa Geograficznego, 8, 47-59.

Troc, M. (1988). Powiązania produkcyjno-przestrzenne zakładu przemysłowego. In: Z. Zioło (ed.), Zakład przemysłowy w akademickim kształceniu nauczycieli geografii. Materiały i Sprawozdania COMSN, 16, Kraków: Wydawnictwo Naukowe WSP, 79-83.

Troc, M. (1991). Kwestionariusz do badania zakładu przemysłowego. In: Z. Zioło (ed.), Problemy przemystu rolno-spożywczego w badaniach geograficznych. Kraków-Warszawa: Centralny Ośrodek Metodyczny Studiów Nauczycielskich, Komisja Geografii Przemysłu Polskiego Towarzystwa Geograficznego, 174-181.

Wajda, E. (2003). Proces kształtowania się Motoroli jako firmy ponadnarodowej. Prace Komisji Geografii Przemystu Polskiego Towarzystwa Geograficznego, 5, 85-114.

Wajda, E. (2006). Rozwój i struktura przestrzenna działalności firmy Nokia w latach 1997-2003. Prace Komisji Geografii Przemystu Polskiego Towarzystwa Geograficznego, 8, 219-240.

Wajda, E., Zorićić-Wołek, M. (2003). Proces kształtowania się korporacji IBM. Prace Komisji Geografii Przemystu Polskiego Towarzystwa Geograficznego, 6, 109-118.

Wójtowicz, M. (2009a). Wpływ globalizacji i integracji w ramach MERCOSUR na wymianę handlową produktów przemysłu samochodowego Brazylii w latach 1990-2006. Prace Komisji Geografii Przemystu Polskiego Towarzystwa Geograficznego, 12, 63-78.

Wójtowicz, M. (2009b). Procesy kształtowania się przemysłu komputerowego w Brazylii. Prace Komisji Geografii Przemystu Polskiego Towarzystwa Geograficznego, 13, 133-142.

Wójtowicz, M. (2011). Wpływ światowego kryzysu gospodarczego na brazylijski i meksykański przemysł samochodowy. Prace Komisji Geografii Przemystu Polskiego Towarzystwa Geograficznego, 17, 129-143.

Zawadzki, S.M. (1962). Zakład przemysłowy jako przedmiot badań ekonomiczno-geograficznych. Przegląd Geograficzny, 2.

Zioło, I. (1978). Załoga kombinatu siarkowego i jej wpływ na przemiany struktury społecznej Tarnobrzeskiego Rejonu Uprzemysławianego. In: Przemiany społeczno-ekonomiczne Tarnobrzeskiego Rejonu Uprzemystawianego. Warszawa: PWN.

Zioło, I. (1968). Zmiana struktury załogi kombinatu siarkowego „Tarnobrzeg” w latach 1963-1965. Zeszyty Badań Rejonów Uprzemystawianych PAN, 26.

Zioło, I. (1973). Struktura pracowników fizycznych kopalni „Jeziorko” na tle wybranych elementów struktury demograficznej. Zeszyty Badań Rejonów Uprzemystawianych PAN, 58. 
Zioło, Z. (1970). Formy koncentracji przemysłu w strukturze przestrzennej województwa rzeszowskiego. Rocznik Naukowo-Dydaktyczny WSP w Krakowie, 40, Prace Geograficzne V.

Zioło, Z. (1972). Próba konstrukcji syntetycznej wielomiernikowej mapy przemysłu. Polski Przegląd Kartograficzny, 3 .

Zioło, Z. (1973). Analiza struktury przestrzennej i form koncentracji przemysłu województwa rzeszowskiego w świetle wybranych mierników. Folia Geographica, Series Geographica-Oeconomica, 6.

Zioło, Z. (1976). Wielomiernikowe mapy specjalizacji przemysłu. Polski Przegląd Kartograficzny, 4.

Zioło, Z. (ed.) (1978a). Przemiany społeczno-ekonomiczne Tarnobrzeskiego Rejonu Uprzemysławianego. In:Seria Problemy Rejonów Uprzemystawianych PAN. Warszawa: PWN.

Zioło, Z. (1978b). Powiązania produkcyjno-przestrzenne Tarnobrzeskiego Okręgu Przemysłowego. Rocznik Naukowo-Dydaktyczny, 62, Prace Geograficzne VII.

Zioło, Z. (1980). Wpływ przemysłu na rozwój społeczno-ekonomiczny regionu rzeszowskiego. In: Seria Problemy Rejonów Uprzemysławianych PAN. Warszawa: PWN.

Zioło, Z. (1982). International Connections of Polish Sulphur Industry. Sao Paulo: Latin American Regional Conference, IGU Commission on Industrial Systems, Department of Geography F.F.L.C.H. USP.

Zioło, Z. (ed.) (1987a). Geografia przemysłu w akademickim kształceniu nauczycieli. In: Geografia przemystu $w$ akademickim kształceniu nauczycieli. Materiały i Sprawozdania COMSN, 14, Kraków: Wydawnictwo Naukowe WSP.

Zioło, Z. (1987b). Próba zarysu teorii struktury przestrzennej przemysłu. Rocznik Naukowo-Dydaktyczny WSP w Krakowie, 112, Prace Geograficzne XI.

Zioło, Z. (ed.) (1988a). Zakład przemystowy w akademickim kształceniu nauczycieli geografii. Materiały i Sprawozdania COMSN, 16, Kraków: Wydawnictwo Naukowe WSP.

Zioło, Z. (1988b). Funkcjonowanie i rozwój przedsiębiorstwa przemysłowego w przesrzeni geograficznej, In: Z. Zioło (ed.), Zakład przemysłowy w akademickim kształceniu nauczycieli geografii. Materiały i Sprawozdania COMSN, 16, Kraków: Wydawnictwo Naukowe WSP, 8-24.

Zioło, Z. (1992). Model powiązań funkcjonalnych otworowej kopalni siarki w przestrzeni geograficznej. In: Stan aktualny i kierunki rozwoju metod otworowych i eksploatacji surowców skalnych. Kraków: Wydawnictwo Naukowe AGH.

Zioło, Z. (ed.) (1994a). Funkcjonowanie przedsiębiorstw przemysłowych $w$ zmieniajacych się warunkach gospodarowania. Materiały i Sprawozdania COMSN, 29, Kraków: Wydawnictwo Naukowe WSP.

Zioło, Z. (1994b). Zmiany otoczenia przedsiębiorstw przemysłowych w nowych warunkach gospodarowania. In: Z. Zioło (ed.), Funkcjonowanie przedsiębiorstw przemystowych $w$ zmieniajacych się warunkach gospodarowania. Materiały i Sprawozdania COMSN, 29, Kraków: Wydawnictwo NaukoweWSP, 13-21.

Zioło, Z. (1996). Model funkcjonowania przestrzeni geograficznej i jego znaczenie dla gospodarki przestrzennej. In: U. Wich (ed.), Gospodarka, Przestrzeń, Środowisko. Lublin: UMCS w Lublinie, Komitet Przestrzennego Zagospodarowania PAN.

Zioło, Z. (1997). Miejsce struktury przestrzennej przemysłu w przestrzeni geograficznej. In: B. Domański (ed.), Geografia, Człowiek, Gospodarka. Profesorowi Bronisławowi Kortusowi w 70. rocznicę Urodzin. Kraków: Instytut Geografii UJ.

Zioło, Z. (1999). Model funkcjonowania przestrzeni geograficznej jako próba integracji badań geograficznych. In: A. Lisowski (ed.), Geografia na przełomie wieków - jedność w różnorodności. Warszawa: Wydział Geografii i Studiów Regionalnych Uniwersytetu Warszawskiego.

Zioło, Z. (2001a). Współczesne tendencje rozwoju przemysłu i ich problematyka badawcza. Prace Komisji Geografii Przemystu Polskiego Towarzystwa Geograficznego, 2, 9-20. 
Zioło, Z. (2001b). Struktura branżowa i koncentracja przestrzenna wiodących światowych firm przemysłowych. Prace Komisji Geografii Przemystu Polskiego Towarzystwa Geograficznego, 3, $29-41$.

Zioło, Z. (2003). Przestrzeń geograficzna jako miejsce realizacji idei ładu przestrzennego. In: Z. Zioło, T. Ślęzak (eds.), Społeczno-gospodarcze i przyrodnicze aspekty tadu przestrzennego. Biuletyn Komitetu Przestrzennego Zagospodarowania PAN, 205.

Zioło Z. (2006). Zróżnicowanie światowej przestrzeni przemysłowej w świetle siedzib zarządów wiodących korporacji. Prace Komisji Geografii Przemystu Polskiego Towarzystwa Geograficznego, $8,9-26$.

Zioło, Z. (2008). Problemy badawcze struktury przestrzennej przemysłu. Prace Komisji Geografii Przemystu Polskiego Towarzystwa Geograficznego, 11, 9-25.

Zioło, Z. (2009). Rola przemysłu w kształtowaniu społeczeństwa informacyjnego. Prace Komisji Geografii Przemystu Polskiego Towarzystwa Geograficznego, 13, 11-20.

Zioło, Z. (2011). Wpływ światowego kryzysu na tempo wzrostu gospodarki i światowych korporacji. Prace Komisji Geografii Przemystu Polskiego Towarzystwa Geograficznego, 17, 9-32.

Zbigniew Zioło, prof. dr hab., Pedagogical University of Cracow, Institute of Geography, Department of Entrepreneurship and Spatial Management. Sc.D., Ph.D. and Professor of Economics. Research interests: spatial management, economic geography, socio-economic policy, economics and policy of regional development.

\section{Adres/address:}

Pedagogical University of Cracow

Department of Entrepreneurship and Spatial Management

Institute of Geography

ul. Podchorążych 2, 30-084 Kraków, Poland

e-mail: ziolo@up.krakow.pl 